\title{
Interpretacje
}

\section{W poszukiwaniu migracyjnego pisania. Kosmopolityka pewnego przypadku literackiego na Wyspach}

Dorota Kołodziejczyk

TEISTY DRUGIE 2016, NR 3, S. 116-147

DOI $10.18318 /$ td.2016.3.7

Nic nie wiedział o Irlandii. Pamiętał tylko, że mają tam guinnessa i śpiewają folkowe piosenki. [...] Śpiewają, grają, i mają robotę. Pierdoliście dużo roboty, wszystko do wzięcia. Nie mieli jej przez jakieś mniej więcej pięćset lat, ale teraz mają i to aż za dużo. Zakładał, że pewne sprawy szybko rozwiążą się same, $\mathrm{z}$ definicji. Wielu ludzi from Bulanda ma takie nadzieje, kiedy wybierają się w te strony. Ponoć w Anglii jest jeszcze gorzej. Podobno na Trafalgar zajeżdżają autokary pełne zdesperowanych wieśniaków, którzy nie mają kasy, bo wszystko wydali już na bilet, ani żadnej umiejętności realistycznego myślenia, ponieważ Bulanda zamordowała ich poczucie realizmu, po czym udają się do pierwszego napotkanego policjanta i krzyczą do niego po polsku: - Gdzie jest robota?'

1 P. Czerwiński Przebiegum życiae, czyli kartonowa sieć, Świat Książki, Warszawa 2009, S. 53-54 i s. 71-72. Pozostałe odniesienia do powieści zaznaczone numerami stron w tekście.

\author{
Dorota \\ Kołodziejczyk - \\ adiunkt w Instytucie \\ Filologii Angielskiej \\ UWr. Członkini Rady \\ Naukowej Centrum \\ Badań Dyskursów \\ Postzaleznościowych, \\ współzałożycielka \\ Centrum Badań \\ Postkolonialno-Post- \\ totalitarnych na UWr. \\ Zajmuje się studiami \\ postkolonialnymi \\ i komparatystyką. \\ Ostatnıe publıkacje: \\ z Cristıną Şandru \\ Postcolonial Perspecti- \\ ves on Postcommu- \\ nism in Central and \\ Eastern Europe (2016). \\ Kontakt: dorota. \\ kolodziejczyk@uwr. \\ edu.pl
}


W literackich świadectwach doświadczenia emigracyjnego po przystąpieniu Polski do Unii Europejskiej i otwarcia rynków pracy dla Polaków dominuje fatalizm podmiotu, który zdaje sobie sprawę z determinizmu granicy między krajami wysokorozwiniętymi a rozwijającymi się - geograficznie rzecz doprecyzowując, między starą a nową Europą. Obie Europy w opowieściach imigrantów z Europy Wschodniej pozostają wobec siebie w relacji fantazmatycznego pożądania, ściśle jednak regulowanego: przybysz z „nowej” Europy jest takim „Innym", jakiego potrzebuje aktualnie rynek pracy kraju przyjmującego. Imigrant, nawet jeśli jest zamknięty w strefie alienującej pracy i mieszkania dzielonego z wieloma takimi jak on, anonimowymi i wymienialnymi przybyszami, rozwija w swej opowieści z owej klaustrofobicznej przestrzeni wizję świata: nomadycznego, poruszonego, napędzanego fundamentalną nierównością szans, a w miejsce stabilnych struktur społecznych oferującego przejściową przynależność i nietrwałe zakorzenienie. W globalnej perspektywie, a na taką skazany jest migrant zarobkowy do starej Europy, choć jest bliskim w końcu tej Europie (przynajmniej geograficznie) Europejczykiem, jest to czysto neo-postkolonialna sytuacja. To właśnie z pozycji podmiotu neo-postkolonialnego nowych narracji migracyjnych, polskich włącznie, wyłania się refleksja krytyczna oparta na doświadczeniu współczesnych nomadów - mobilnej siły roboczej. W badaniach nad globalizacją, które zajmują się formami, jakie przybiera nowa świadomość świata, nazywa się to kosmopolityką raczej niż kosmopolityzmem² - ponieważ chodzi tutaj o performatywny aspekt „polityki” jako aktywnej refleksji o świecie, która wcale nie musi łączyć się z poczuciem przynależności do świata (cosmopolis). Kosmopolityka nowej narracji migracyjnej ${ }^{3}$ daje okazję do wypracowania nowej epickości - a ściślej, owe dwie cechy tworzą razem syntagmatyczny (kombinacyjny - kosmo-polityczny) i paradygmatyczny (asocjacyjny - epicki) wymiar narracji migranta.

Powieści Piotra Czerwińskiego Przebiegum życiae (2009) i Międzynaród. (2011) posłużą mi za przykład migracyjnego pisania, które wychodzi poza formułę biegunowego umieszczania migracyjnego podmiotu między domem

2 P. Chea Introduction - Part II: the Cosmopolitical - Today, w: Cosmopolitics: Thinking and Feeling Beyond the Nation, ed. P. Cheah, B. Robbins, University of Minnesota Press, Minneapolis 1998, S. 20-41.

3 Na temat migracyjnego pisania jako kosmopolityki zob. B. Ghosh When Borne Across: Literary Cosmopolitics in the Contemporary Indian Novel, Rutgers University Press, New Brunswick-New Jersey 2004. 
a nowym krajem i lokuje go w przestrzeni krytycznego kosmopolityzmu. Teksty Czerwińskiego oraz wiele innych prozatorskich utworów Polaków pracujących na Wyspach Brytyjskich przedstawiają nową przestrzeń światowości (posługując się terminem Edwarda Saida4), którą migrant poznaje jako dyskursywną mapę nadpisującą się na jego cielesnym doświadczeniu 5 ruchu przez granice, języki i społeczne praktyki codzienności. U Czerwińskiego historia bohatera łączy się z intensywną refleksją historyczno-kulturową, która w patetyczno-ironicznym tonie pokazuje niemoc wyobrażeniowych konstruktów typu przyjaźń i bliskość narodów (podanych jako pijackie rojenia lub narracyjne ekscesy), kondycję migranta każe zaś widzieć jako nieuchronnie ryzykowną graniczność na wielu poziomach, a tym pierwszym, najważniejszym, jest trudne lub niemoźliwe zadomowienie, stan skazujący migranta na status podrzędności. Kosmopolityzm migranta jest więc świadomością świata specjalnego rodzaju - jest to kosmopolityka subalterna, który z jednej strony wydaje się wykluczony z obiegu znaczeń, a z drugiej, budując swoją narrację w "zaklętych rewirach"6 przestrzeni podrzędnych, wprowadza do obiegu literackiego ważny głos krytyczny.

Gustaw, bohater Przebiegum życiae, postanawia szukać jej za granicą. Wybór, dość przypadkowy, pada na Irlandię - w Polsce nie ma dla niego przyszłości, a plotka głosi, parafrazując narratora, że na emigracji „no future przebiega mniej boleśnie” (51). Bogate CV i dyplom SGH „bardzo very embe-a” (54) mają zapewnić mu karierę wysokiej klasy ekonomisty, którego kwalifikacje są niezbędne dla rozwoju gospodarczego Irlandii. Optymistyczną wizję dopełnia stylizacja na angielskiego gentlemana (płaszcz z wielbłądziej wełny,

4 U Saida "światowość" jest podstawowym terminem krytycznym, odnoszącym się do etosu krytyki jako praktyki czytania wykraczającej poza tekstualizm teorii. Zob. E.W. Said Introduction: Secular Criticism, w: tegoż The World, the Text, and the Critic, Faber and Faber, London 1983, S. 1-30.

5 M. de Certeau w znanym pasażu z The Practice of Everyday Life, trans. S. Rendal, University of California Press, Berkley (1984) 1988, pisze o chodzeniu jako „elementarnej formie doświadczania miasta" (93) i dyskursywnych mapach doświadczanych cieleśnie (54). Mapa nie jest ontologicznym pewnikiem, lecz totalizującą organizacją przestrzeni; cielesne rysowanie szlaków miasta jest jednym ze sposobów podważania autorytetu (i autorytarności) mapy.

6 Ł. Ślipko Pokój z widokiem na Dunnes Stores, Wydawnictwo RB, Opole 2011, s. 8. Autor postarał się w tekście o irlandzkim pubie na lotnisku w Cork obsługiwanym przez imigrantów z Europy Środkowej i Wschodniej o to ważne kulturowo odniesienie do filmu Janusza Majewskiego z 1975 roku, opartego na powieści Henryka Worcella z 1936 roku. Można również przypuszczać, że w tytule tej autobiograficznej prozy zawiera się odniesienie do powieści E.M. Forstera A Room with a view, 1908 . 
garnitur na miarę, krawat na zamówienie) w ubiorze i wymowie w języku docelowym. Oczywiście Irlandia nie okazuje się rajem ani ziemią obiecaną dla emigranta z Polski. Gustaw musi szybko nauczyć się podstawowych zasad życia na szmaragdowej wyspie: jego akcent, imitujący wymowę królowej brytyjskiej, Irlandczyków w najlepszym wypadku rozśmieszy, w najgorszym zirytuje; jego CV i dyplom ich przestraszą - agencje pośrednictwa pracy nawet nie wezmą tych dokumentów pod uwagę, kierowane żelazną logiką, że Polak ma w Irlandii określone zadania; przy odrobinie szczęścia i dużej determinacji pracę dostanie jedynie w sektorze 3Ds ${ }^{7}$. W mieście będzie poruszał się w przestrzeni wyznaczonej trasą kolejki Luas, z której korzystają prawie wyłącznie imigranci; irlandzcy „autochtoni”, jak nazywa ich narrator, poruszają się w obrębie swojej, zastrzeżonej, przestrzeni korporacyjnej średniej klasy. Irlandia okazuje się krajem pławiącym się w chwilowej koniunkturze ekonomicznej i bezproblemowo powielającym wzorce neoliberalnego wyzysku, wolna od niewygodnej pamięci historycznej, która kazałaby jej mieszkańcom kojarzyć korporacyjne zachowania wobec imigrantów z latami kolonialnej opresji ze strony brytyjskiego imperium. W tej przygnębiającej aurze, dodatkowo pogłębianej idiosynkrazjami irlandzkiej pogody, która nie pozwala odróżnić lata od zimy, Gustaw popada w dwubiegunowe szaleństwo: pisze scenariusz filmowy, wierząc głęboko, że zainteresuje nim jakiegoś irlandzkiego producenta, lub poddaje się niemal katatonicznej alienacji w absurdalnie enigmatycznej fabryce, gdzie zajmuje się wrzucaniem pudeł do ogromnej niszczarki, i crappy hausie, gdzie mieszka razem z takimi jak on Polakami. Imigrant z marzeniami może być tylko wariatem, ponieważ nie przyjmuje do wiadomości porządku rzeczy: „Jesteśmy pieprzonymi Polakami. Jesteśmy tu po to, żeby czyścić ich kible i zbierać ich pety z trawników. Nie potrzebują nas do pisania scenariuszy" (262); znowu imigrant bez marzeń to tylko reprezentant „gównianych ludzi” wykonujących „gówniane prace" (87).

Nowa literatura emigrantów z Polski na Wyspach siłą rzeczy przedstawia relacje między przybyszami z „nowej” Europy i tamtejszymi, lecz doświadczenia imigranta są wpisywane w szerszą perspektywę procesów globalizacyjnych. Korporacyjny styl pracy i kultura konsumeryzmu wysuwają się tutaj na pierwszy plan, daleko przed wielokulturową mozaiką, specyficznie

7 Akronim (dirty, dangerous, demeaning - brudne, niebezpieczne, poniżające) odnoszący się do charakteru prac wykonywanych przez imigrantów, gdy brakuje chętnych do ich wykonywania w kraju przyjmującym. 
brytyjską klasowością i charakterystyczną dla Wysp lokalnością akcentów. Przestrzeń imigranta jest często ograniczona do sektora 3Ds, i jest to jednocześnie przestrzeń nowej światowości. W takiej właśnie klaustrofobiczno-kosmopolitycznej przestrzeni wypełnianej natrętną powtarzalnością albo ucieczką w metafikcyjne narracje, rysuje się kondycja współczesnego migranta. Imigrant, choć jest skazany na sektor 3Ds, daje świadectwo czasu o epickim wymiarze, w którym opowieść o Polakach na wyspach brytyjskich łączy się z gorzkim, autoironicznym komentarzem o świecie jako miejscu brutalnych zderzeń wyobrażeń z odzierającą ze złudzeń rzeczywistością. Rdzeniem tej rzeczywistości jest utowarowienie wszystkiego, łącznie z tożsamością, różnicą kulturową i integracją europejską. Wielokulturowość, która mogłaby być projektem otwartego społeczeństwa, imigrantów z nowej Europy nie dotyczy: na ich kulturowe marki nie ma popytu, ,autochtoni” zaś są już tylko symulakrami irlandzkości, podtrzymywanymi przy życiu przez korporacyjnego ducha.

Fala emigracji po otwarciu zachodnioeuropejskich rynków pracy w latach rozszerzania Unii Europejskiej o państwa Europy Środkowej i Wschodniej dogłębnie zmieniła pejzaż społeczny krajów do tej pory kojarzonych z imigracją ze swoich byłych kolonii, a zatem z pewnym etycznym wobec nich zobowiązaniem. Inwazja z bliskiej, a jednak do niedawna bezpiecznie odseparowanej kordonem żelaznej kurtyny, muru berlińskiego, reglamentowanego dostępu do paszportów w reżimach komunistycznych, a wreszcie strachu samej Europy przed milionami, których nic miało nie powstrzymać przed opuszczeniem postkomunistycznej mizerii i wyrwaniem się do lepszego, zachodniego świata, wywołała w starej Europie burzliwe emocje. Otwarcie to miało silny afektywny oddźwięk - strach przed „nowymi” Europejczykami był artykułowany całkiem bezpośrednio, na wszelkich poziomach dyskursu publicznego, od ulicy po wielką politykę, co w obliczu obecnego kryzysu humanitarnego związanego z uchodźcami z Syrii może wydać się porównawczym paradoksem. Po pierwsze, Europa Zachodnia po upadku reżimów komunistycznych utraciła „powód” swojego pożądania wobec krajów Europy Środkowej i Wschodniej. Do tej pory fantazja o wschodniej Europie wzmacniała dość bezproblemowo narcystyczne wyobrażenie Europy o sobie jako ostoi demokracji i wszelkich wolności; po otwarciu Unii Europa musiała stanąć twarzą w twarz ze swoim strachem, że oto Europa Wschodnia jest zupełnie czymś innym, niż być powinna. Obiekt fantazji miał być lustrem, w którym Europa podziwiała swoją urodę etycznego ideału. Granica nadawała tej relacji formę, Europy po obu jej stronach mogły do woli podsycać wzajemne pragnienia, 
nieświadome, że eros - pozorna treść tych fantazji - to jedynie porządkująca formuła Symbolicznego ${ }^{8}$.

Tymczasem po zniesieniu granicy podziału na Europę komunistyczną i demokratyczną obiekt fantazji - Europa Wschodnia - stał się rzeczywisty i groźny w swej dostępności, ujawniając się jako z jednej strony „nieuchwytny, absolutny Inny, który pozostaje niezgłębioną tajemnicą", a z drugiej, co gorsze, jako mała różnica (object petit a?) - „nieznaczna cecha, której obecność magicznie przeistacza swojego nosiciela w obcego"10. Andrzej Stasiuk, rozwijając w Fado fantazję o inwazji wschodnioeuropejskich barbarzyńców (w porządku alfabetycznym) na starą Europę, którą pogrążą w apokaliptycznym chaosie, uaktywnia wizję strachu Europy przed absolutnym, spotworniałym Innym, a jest nim, jak pisze, „« «pas ludności mieszanej», jak nazywała Hannah Arendt zmienne i amorficzne przestrzenie zagubione gdzieś między Niemcami a Rosją"11. W wybujałej formule groteski autor Fado pokazuje, przez strategię przejęcia stereotypu, co Europa Zachodnia ukrywa pod językiem legalizmu i troski społecznej: odsłania głębszą treść tego, co w innej formule w postaci sławnego polskiego hydraulika ${ }^{12}$ - było próbą okiełznania strachu przed napływem imigrantów z „nowej” Europy. Polski hydraulik to propozycja oswojonego i użytecznego Obcego. Na polskim plakacie, którego koncepcja podobnie opiera się na strategii ironicznego przejęcia stereotypu, hydraulik jest nie tylko wykwalifikowany - jest też przystojny i świadomy swego uroku. Jego rolą jest uwodzić - i tak oto wzajemnym relacjom obu części Europy zostaje przywrócona ich właściwa formuła - erotyzm jako płaszczyzna performatywna, gra różnic i fantazji, wytwarzana przez coraz mniej oczywistą granicę między wschodem a zachodem Europy. Brak tej oczywistości nie tylko destabilizuje stary porządek wzajemnego romansu, bo odbiera mu jego przyczynę, jak pisze Svetlana Boym, opierając się na eseju Dubravki

8 S. Žižek Psychoanalysis and the Lacanian Real: 'Strange Shapes of the Unwarped Primal World', w: Adventures in Realism, ed. M. Beaumont, Blackwell Publishing, Oxford 2007, s. 210.

9 Tamże, s. 217.

10 Tamże, s. 211.

A. Stasiuk Fado, Czarne, Wołowiec 2006, s. 82.

Zob. dyskusję kategorii "polskiego hydraulika", terminu użytego po raz pierwszy przez Fritsa Bolkesteina, holenderskiego polityka i autora dyrektywy o usługach na rynku wewnętrznym w 2005 roku, w: A.-M. Fortier The Politics of Scaling, Timing and Embodying: Rethinking the 'New Europer, ",Mobilities" 2006 vol. 1, no. 3, DOI: 10.1080/17450100600915992, S. 313. 
Ugrešić ${ }^{13}$, ale też wprowadza do wzajemnej relacji nową, fundamentalną trudność - niesamowity aspekt podobieństwa: „Kochanka ze wschodu jest dla mężczyzny z zachodu jego lustrzanym odbiciem, lecz tym razem jest to odbicie w pękniętym lustrze. Im bardziej ona wydaje się zeuropeizowana, tym bardziej on obawia się bałkanizacji. «Proces cywilizacyjny», który tak łatwo jej przyszedł, może wskazywać na płytko ukrytą, wewnętrzną barbarzyńskość zachodniego kochanka"14. Od spotworniałego Innego w Fado do strachu przed Obcym, który okazuje się częścią siebie, to Lacanowskie namnażanie się Realnego w różnicy jako potworności i jako małej, nieznacznej zmiany (ale wskazującej ostatecznie na potworność). Imigrant z Europy Środkowej i Wschodniej - wciąż Europy, ale jednak Europy innej i niesamowitej w swym podobieństwie do Europy właściwej - to jedno z najbardziej masowych, a jednocześnie indywidualizujących się i proteuszowych wcieleń „otchłani podmiotowości”15, w której Inny jest Rzeczą - „tym, co potencjalnie czai się pod każdą swojską ludzką twarzą"16.

Nie oznacza to, że każda narracja migracyjna wikła się w tego rodzaju scenę nieznośnego i niezgłębionego pożądania - ale na pewno każda narracja migracyjna w szczególny sposób mobilizuje i uaktywnia głębię konfrontacyjnej relacji podmiotowości. Opowieść, której tematem jest migracja, kojarzy się zazwyczaj z procesem przemiany, rozbudowania, przepytywania czy też może przepracowania tożsamości. Z pewnością przekroczenie granicy, która dzieli życie na nowe i stare (bo nie każde przemieszczenie będzie przecieź migracja), zmusza do przeformułowania kostiumu dyskursywnego, którym jest tożsamość. Ale czy narracja migracyjna zawsze jest dochodzeniem do toźsamości, czy zamyka się w takim właśnie teleologicznym procesie? Znamienne są uwagi na ten temat pisarzy-migrantów, których twórczość krytycy chętnie łączą z refleksją tożsamościową. Dubravka Ugrešić wprost mówi o tożsamości jako obciążeniu, presji i utowarowionym produkcie społecznym ${ }^{\mathbf{1 7}}$. Salman Rushdie, postrzegany, zapewne słusznie, jako piewca dynamicznie hybrydyzującej się tożsamości migranta („drzewo-chimera”, „byt w przekładzie”),

13 S. Boym The Future of Nostalgia, Basic Books, New York 2001, s. 244 [przeł. D.K.].

14 Tamże, s. 244 [przeł. D.K.].

15 S. Žižek Psychoanalysis and the Lacanian Real..., S. 216.

16 Tamże, s. 217.

17 D. Ugrešić Nobody's Home. Essays, trans. E. Elias-Bursać, szczególnie: Stereotypes, Identity i The Alibi of Cultural Differences, or, How I got the Picture, Telegram, London 2007. 
rozwija w kolejnych powieściach postać migranta, który zawsze wyprzedza pomyślane formy tożsamości - te istniejące zostawił już za sobą, nie należy do narodu, etnosu czy religii, jest raczej mobilnym uczestnikiem przynajmniej w niektórych z tych tożsamościowych form, ale bardziej na zasadzie styczności i przygodności niż dziejowego związania. Inga Iwasiów w szkicu Hipoteza literatury neo-post-osiedleńczej rozważa (nie) moźliwość ujęcia „literatury europejskiej po 1945 roku jako literatury wielkiego przemieszczenia. Napisanie takiej książki (słownika? przewodnika? reportażu? powieści?) wydaje się zadaniem tyleż pilnym, co karkołomnym. Pilnym, ponieważ dysponujemy do niej narzędziami, teoriami: nomadyzmu, postkolonializmu, gender, nowego historyzmu, zwrotu terytorialnego, zwrotu politycznego itd. Karkołomnym, ponieważ nieprzebrany jest katalog tekstów różnogatunkowych, wielojęzycznych, $w$ dodatku poruszających wiele tematów w rozmaity sposób związanych z doświadczeniem przesiedlenia"18. Monografia taka byłaby projektem utopijnym nie tylko w sensie potocznym, w którym zostaje podkreślona praktyczna niemoźliwość tego przedsięwzięcia, ale także wprost korespondującym z literackim sensem utopii - dostarczyłaby dowodów, że doświadczenie przemieszczenia, a z tym nasze poczucie sensu historii, przynależności i tożsamości wreszcie, będzie coraz bardziej determinować nasze bycie w świecie. Warto przede wszystkim zauważyć, że migracja jest właśnie próbą realizacji utopii: przemieszczeniem w czasie (ku przyszłości) i przestrzeni (jakościowe oddalenie od dotychczasowego miejsca na skutek przekroczenia granic - państwowych, kulturowych, cywilizacyjnych). Migracja jest też przede wszystkim intensywnym procesem wyobrażeniowym, który zmusza podmiot do projektowania siebie na nowe siatki znaczeń i wprowadza go w nowe systemy komunikacyjne na poziomie języka, bardzo szeroko rozumianej kultury, ale też jak najbardziej materialnego wchodzenia w nową tkankę rzeczywistości.

W tym kontekście - utopijności wpisanej w doświadczenie migracji i widocznej w zapisach tego doświadczenia - rozwija się dyskusja, czy w dobie przemieszczeń na globalną skalę, które można obserwować (lub w nich uczestniczyć) przez całą nowoczesność, a szczególnie teraz, kiedy mobilność staje się moźliwa jak nigdy dotąd, dzięki umasowieniu lotów, można jeszcze mówić o istnieniu literatury emigracyjnej, czy nie mamy raczej do czynienia z literaturą migracji (przemieszczeń wielokrotnych i wielokierunkowych) lub

18 I. Iwasiów Hipoteza literatury neo-post-osiedleńczej, w: Narracje migracyine w literaturze polskiej XXiXXIwieku, red. H. Gosk, Universitas, Kraków 2011, s. 210. 
literaturą nomadyzmu. W poszukiwaniu metodologii badań takiej literatury zwraca się uwagę na konieczność łączenia refleksji literaturoznawczej z naukami społecznymi, szczególnie w obrębie studiów nad mobilnością (mobility studies), socjologią przemieszczeń i antropologią kulturową globalizacji19 ${ }^{19}$ W polskim wariancie tego namysłu dwie kwestie wysuwają się na pierwszy plan: 1) jak włączyć do nurtu badań nad literaturą przemieszczeń (migracyjną) literaturę powojennych migracji ludności na skutek zmian granic państwowych i promowania polityki jednolitych narodowościowo państw i 2) jak nazwać literaturę nowych emigrantów - tych, którzy opuścili kraj po przełomie ustrojowym i po przystąpieniu do Unii Europejskiej i otwarciu europejskich rynków pracy.

W pierwszym zarysowanym obszarze literatury, która miałaby się nazywać migracyjną, Bogusław Bakuła widzi miejsce dla „utworów, w których zostaje ukazana powojenna rzeczywistość dobrowolnych i niedobrowolnych przemieszczeń zbiorowych, i gdzie bohaterem literackim, obok jednostki, jest również określona grupa społeczna lub etniczna, zaś obszarem dziania się rodzima powojenna rzeczywistość"20. Podobnie jak Inga Iwasiów, autor podkreśla historyczną i egzystencjalną ważkość „deportacji, repatriacji i przesiedleń po roku 1945"21. Literackie formy zapisu tego masowego doświadczenia, które Inga Iwasiów klasyfikuje jako narracje osiedleńcze, potem przesiedleńcze, a w końcu neo-post-osiedleńcze ${ }^{22}$, dla obojga krytyków przedstawiają ogromny potencjał epicki: nowe kresy, pisze Bakuła, północne i zachodnie (przy świadomości politycznego obciążenia tego terminu, traktowanego tutaj jako umownego) to "pytanie o wielki temat polskiej epiki”23. Inga Iwasiów dostrzega w regionalizmie i lokalności narracji „neo-post-przesiedleńczych" ów nowy wymiar epicki, który łączy zbiorowe doświadczenie historii z mobilizacją form pamięci ukierunkowanych na rewizje poprzednich narracji (historycznych, ideologicznych) na planie zbiorowym i rodzinnym,

19 U. Beck Mobility and the Cosmopolitan Perspective, w: Tracing Mobilities: Contributions from the Cosmobilities Network, ed. W. Canzler, V. Kaufmann, S. Kesserling, Ashgate, Farnham 2008, s. 25-34; A. Appadurai Nowoczesność bez granic. Kulturowe wymiary globalizacii, przeł. Z. Pucek, Universitas, Kraków 2005.

20 B. Bakuła Między wygnaniem a kolonizacią. O kilku odmianach polskieipowieści migracyjneiw XX wieku (na skromnym tle porównawczym), w: Narracje migracyine..., s. 164.

21 Tamże, s. 166.

22 I. Iwasiów Hipoteza literatury neo-post-osiedleńczej, s. 209-210.

23 B. Bakuła Między wygnaniem a kolonizacja..., s. 166. 
w postaci międzypokoleniowych przemian pamięci w postpamięć. Literatura wyłaniająca się z tego intensywnego dialogu z przeszłością, która jest i rewizją, i przejęciem, która „tłumaczy kondycję bohatera niewypowiedzianą traumą jego przodków" ${ }^{24}$, wpisuje się w utopijny plan monografii literatury przemieszczeń, łączącej na wielkim planie komparatystycznym literaturę polską z europejską.

W drugim obszarze literatury migracyjnej, ,powstającej poza Polską"25, wyjściową kwestią problematyczną jest sama kategoria literatury emigracyjnej. Okazuje się ona nieadekwatna dla określenia literatury tworzonej obecnie, ponieważ odnosi się do historycznie zamkniętego okresu zniewolenia i zależności politycznej, a więc tego rodzaju doświadczenia opresyjnej historii, który nie pojawia się w literaturze po przełomie ustrojowym i który wobec tego nie nadaje jej specyficznego etosu, jaki ją do tej pory wyróźniał, a przede wszystkim determinował. Małgorzata Zduniak-Wiktorowicz obszernie relacjonuje tę terminologiczną debatę w książce Wspótczesny polski pisarz w Niemczech - doświadczenie, tożsamość, narracja (2010). Rozważając potencjał kategorii literatury „postemigracyjnej”, autorka podkreśla rewizyjny efekt przedrostka „post," idąc za przykładem krytyki postkolonialnej: „«Post» nie jest tu świadectwem pożegnania z emigracyjnym kluczem, ale zachętą do oglądu «zjawisk występujących później», a przez to pozostających - również przez bezpośrednią negację - w ścisłym związku z szeroko traktowaną kondycją emigracyjną"26. Dodatkowo, poza szerokim spektrum pokrewieństw (autorka wzmiankuje tutaj dopuszczanie w nowej literaturze hybrydowych form tożsamości, w przeciwieństwie do poprzedzającego formatu emigracyjnego pisania), kluczowa jest inskrypcja przezwyciężenia zależności, widoczna w przedrostku „post"27. W ten sposób „post” nie tylko koduje przełom ustrojowy, ale też wpisuje refleksję nad literaturą (e)migracyjną w horyzont refleksji postzaleźnościowej, na co autorka także zwraca uwagę. Najważniejszym jednak argumentem za odejściem od monolitu literatury emigracyjnej i, przykładowo, opatrzeniem literatury pisanej poza krajem przedrostkiem „post”, jest inny niż dawniej status pisarza emigracyjnego.

24 I. Iwasiów Hipoteza literatury neo-post-osiedleńczej, s. 224.

25 Kategoria zastosowana zastępczo przez Małgorzatę Zduniak-Wiktorowicz, Współczesny polski pisarz w Niemczech - doświadczenie, tożsamość, narracja, Wydawnictwo Poznańskie, Poznań 2010, s. 11, jako sygnał toczącej się debaty nad uży tecznością kategorii „literatury emigracyjnej”. 
Inne kategorie pozostają względne - emigrant raczej nie uważa się już za uchodźcę, ale nawet ta kluczowa różnica w odniesieniu do literatury sprzed 1989 roku może być kwestią albo indywidualnej oceny, albo w końcu zmiennej historii. Etos literatury emigracyjnej determinował przecież przede wszystkim pisarza - jako tego, który musi dać słowo oczekującemu na nie narodowi, tym bardziej że sam znajduje się w przestrzeni wolności. „Post” owo zdeterminowanie rozluźnia, robi miejsce dla rewizji, a nawet odrzucenia etosu pisania emigracyjnego. Oczywiście „post” utrzymuje również związanie pisarza piszącego z "zewnątrz" - sam temat migracji lokuje bohatera, narratora, głos autora itd. w przestrzeni ograniczonej biegunami ojczyzny/ kraju/polskości i nowego kraju/nowej ojczyzny/miejsca (czasowego) wyjazdu. Toźsamość emigranta jest toźsamością zmobilizowaną - staje się ona aktywnym czynnikiem w życiu bohatera literackiego, niezależnie od jego/ jej woli. W pisaniu postemigracyjnym dwubiegunowość kondycji emigranta nie jest już jednak bezwzględna, a tożsamościowa mobilizacja podobnie przyjmuje charakter otwartej gry. W próbach ustalenia nowej, adekwatnej terminologii dla różnych nurtów pisania inspirowanego doświadczeniami przemieszczeń nie chodzi o powierzchowną innowacyjność - nowa epoka, nowy termin, nowa dyscyplina - lecz o nadanie refleksji krytycznoliterackiej i kulturowej w tym obszarze odpowiedniej struktury, która byłaby w stanie ukazać wzajemne powiązania między różnymi terytoriami i formami migracyjności.

Z pewnością kategoria literatury migracyjnej połączyłaby wyraźnie odmienne, a jednak pozostające w dialogu nurty zapisu doświadczenia przesiedleń/przemieszczeń, szczególnie mocno zaznaczających się w okresach przełomów historycznych, i równoległe do literatury emigracyjnej. Literatura przesiedleńczo-osiedleńcza oraz jej „neo-post” rewizje i innowacje wnosiłyby do zasobów literatury migracyjnej ogromne archiwum wielogatunkowych narracji o przekraczaniu granic (państw, kultur, tożsamości) determinowanych wielką globalną polityką, która ma dosłowne przełożenie na życie całych społeczności. Ten wątek stanowi również dobry materiał komparatystyczny dla odniesień do innych, niegdyś komunistycznych państw, które podobnie kształtowały swoją politykę narodowościową i dokonywały przetasowań etnicznych na dużą skalę, ale też dla odniesień do innych, wielkich przełomów politycznych w państwach postkolonialnych, w których wyzwolenie się spod władzy imperium często łączyło się z obraniem kursu na politykę państwa narodowego, co skutkowało wielkimi przemieszczeniami ludności według klucza religijno-etniczno-językowego i związanymi z tym traumatycznymi 
doświadczeniami ${ }^{28}$. Literatura migracyjna łącząca nurty literatury migracji wewnętrznych, emigracyjnej i postemigracyjnej ukazuje istotowość przemieszczenia (wykorzenienia, przesiedlenia, przeniesienia) w późnej nowoczesności na poziomie lokalnym, regionalnym i globalnym jednocześnie i jako taka stanowi bogaty zasób kognitywnych, afektywnych i wyobrażeniowych modeli bycia w świecie dla tych, dla których miejsce jako konotacja przynależności i bycia u siebie dawno przestało być kategorią niewymagającą refleksji.

Rozpoznanie w pisaniu migracyjnym wyraźnego podłoża postzależnościowego i styczności z literaturą postkolonialną każe pójść dalej, w kierunku komparatystyki, chciałoby się powiedzieć, geopolitycznej - takiej, która w szerokiej perspektywie terytorialnej (literatura narodowa, literatura składająca się na region - środkowo-wschodnioeuropejska, literatura del postkolonialna ${ }^{29}$ ) pokaże, że szczególnie literatura migracyjna - literatura przemieszczeń - wypracowuje nowe formy kosmopolitycznej wyobraźni ${ }^{30}$ i kosmopolitycznego zakorzenienia ${ }^{31}$ oraz pozwala dostrzec nowe konfiguracje miejsca jako interfejsu między przestrzenią globalności i przestrzenią terytorialności ${ }^{32}$.

W nowej literaturze migracyjnej krytyk powinien szczególnie uważnie poszukiwać sygnałów owej światowości, która pozwala wychodzić poza biegunowo skonstruowaną relację migrant - naród i zachęca do śledzenia ideologicznych, kulturowych, kognitywnych i afektywnych szlaków rysujących mapę przynależności do świata. Migracyjna kosmopolityka to jeden z najważniejszych projektów wyłaniających się z porównawczego czytania współczesnej literatury (e)migrantów. „Polityka”, poni eważ migracje łączą się

28 Na przykładzie subkontynentu indyjskiego: podział Indii na Indie i Pakistan, separatyzm w Kaszmirze, oderwanie się Bangladeszu (wcześniej: Wschodniego Pakistanu) od Pakistanu wszystkie te wydarzenia skutkowały ogromnymi migracjami ludności.

Zob. M. Tlostanova, W. Mignolo Learning to Unlearn. Decolonial Reflections from Eurasia and the Americas, Ohio State University Press, Columbus 2012, s. 83-121. A. Appadurai Nowoczesność bez granic..., s. 82-97, oraz tegoż Grassroots Globalization and Research Imagination, w: Globalization, ed. A. Appaduraj, Duke University Press, Durham 2000, s. 8.

K.A. Appiah Cosmopolitan Patriots, w: Cosmopolitics: Thinking and Feeling Beyond the Nation, s. 91-114 oraz tegoż Cosmopolitan Reading, w: Cosmopolitan Geographies: New Locations in Literature and Culture, ed. V. Dharwadker, Routledge, London 2001, s. 222-223. tive: Sociology of the Second Age of Modernity " The British Journal of Sociology" 2000 vol. 51, no. $1,5.90$. 
z wieloaspektowym przekraczaniem granic, a to z kolei jest częścią większej geopolityki przemieszczeń, wobec której muszą się jakoś sytuować. „Kosmo", ponieważ kaźde takie przekroczenie granicy jest aktem otwarcia na świat, poznania świata i wyobrażenia go sobie w performatywnym i materialnym sensie. Kosmopolityzm migrantów byłby więc inny od kojarzonego z uprzywilejowanym statusem kosmopolityzmu oświeceniowego. Byłby właściwie procesem, a nie stanem czy też atrybutem określającym osobę o dużej wiedzy, obyciu i świadomości świata. Ulrich Beck proponuje badać „łańcuchy kosmopolityzacji”33, które tworzyły świat od dawna. Można je dostrzec w historii handlowych szlaków transkontynentalnych, odtwarzanych w powieściach Amitava Ghosha The Glass Palace i The Sea of Poppies, w szlakach migracji poprzedzających współczesną globalizację, opisywanych przez tego samego autora w jego studiach antropologiczno-literackich ("The Imam and the Indian"), a także w szlakach (często przecinających łańcuchy górskie) prowincjonalnych czy peryferyjnych kosmopolityzmów, których przykłady widać chociażby w prozie Stasiuka, ale także u Tokarczuk, czy też transkontynentalnych szklaków postsowieckiego, Azjatycko-Europejskiego handlu, którego żywym, epickim przykładem był Jarmark Europa. Owe historyczne i współczesne kręgi kosmopolityzacji tworzą formy bycia w świecie, których ważną cechą jest ich często wielomiejscowe zakorzenienie $e^{34}$. Nowa migrancka kosmopolityka rozwija się na gruncie, można by rzec, pękniętym i niepewnym - Salman Rushdie często używał w swoich powieściach figury migracji jako takiej formy bycia, w której osoba decydująca się opuścić swój kraj pozostawia za sobą grawitacyjną siłę narodowego przywiązania i wchodzi w strefę migracyjnej nieważkości ${ }^{35}$. Nieznośna czasami lekkość migracyjnego bytu w powieściach Rushdiego w wielu innych powieściach, jak chociażby Kiran Desai Brzemie rzeczy utraconych (2006, polskie wydanie 2007) czy Moniki Ali Brick Lane (2003, polskie wydanie 2009) zostaje skonfrontowana z siłą grawitacyjną ryzyka.

Obraz świadomości świata współczesnych migrantów w globalnych przepływach, który wyłania się z bogatego archiwum tekstów w światowym obiegu literackim, stanowi podłoże komparatystyczne badania kluczowych

33 U. Beck Mobility and the Cosmopolitan Perspective, s. 31.

34 B. Robbins Introduction Part I: The Actually Existing Cosmopolitanism, w: Cosmopolitics: Thinking and Feeling Beyond the Nation, S. 2, oraz A. Appadurai Cosmopolitanism from Below: Some Ethical Lessons from the Slums of Mumbai, "The Salon" 2011 Vol. 4, No. 32.

35 S. Rushdie Wstyd i Szatańskie wersety. 
węzłów tematycznych literatury migracyjnej, w tym szczególnie: migracje ze stref nowoczesności peryferyjnych ${ }^{36}$ do krajów tworzących rdzeń nowoczesności; diaspory i ich relacje z domem na odległość w nowej formule transnarodu ${ }^{37}$; migracyjne formacje i nacjonalistyczne mobilizacje tożsamościowe na odległość wpływające na politykę swoich krajów ${ }^{38}$; fale afektów, szczególnie w obszarze poczucia wyobcowania i przynależności; i, wreszcie, ostatni, lecz bodaj najważniejszy temat: przestrzenie podrzędności (obozy dla uchodźców, obozy przejściowe, nielegalne obozy nielegalnych migrantów) i podmioty podrzędne (subalterni w różnych kontekstach społeczno-kulturowych: nielegalni robotnicy, kobiety, niepełnosprawni, bezdomni, uchodźcy bez statusu uchodźcy).W takim porównawczym ujęciu literatur migracyjnych przez języki i kultury można wychwycić systemowość migracyjnej kondycji i znaleźć punkty czy też miejsca sprawczości, przez którą migranci zajmują miejsce w świecie, kreują swoje środowisko i, słowem, wdrażają swoją kosmopolitykę.

U Czerwińskiego w Przebiegum życiae napotykamy wiele momentów geopolitycznej ironii, jak choćby ta o palimpsestowym nakładaniu się kolonialnych opresji:

Ogólnie rzecz biorąc, Irole i Angole mieli długotrwały związek sadomaso, który najwyraźniej nie był szczęśliwy. Kinda trochę przypominało to romanse Bulandy z jej egzotycznymi sąsiadami, którzy przez ostatnie tysiąc lat pragnęli wydymać Bulandęi zrobić z niej mydło albo wysłać na holiday in Cyberia. Aleśmy się nie dali. Kto żyw uciekał z Bulandy za granicę. [...] Irole mieli dokładnie takie same przygody, myślę więc, że obie nacje powinny się naprawdę cieszyć, że w końcu odlazły się nawzajem na świecie. [...] Angole byli w Irolach so in love, że zostawili im na pamiątkę język angielski. Egzotyczni sąsiedzi Bulandy próbowali tej samej sztuczki, aleśmy się nie dali, jak już wspomniałem. To dlatego wszyscy mówimy po polsku i nikt nas nie rozumie. $(77-78)$

36 C. Bartolovich, N. Lazarus Marxism, Modernity and Postcolonial Studies, Cambridge University Press, Cambridge, MA 2002, s. 15; N. Lazarus Kosmopolityzm a lokalność w literaturze światowej, przeł. D. Kołodziejczyk " Porównania" 2013, nr 13, s. 29-46. ed. J. Wilson, C. Sandru, S. Lawson-Welsh, Routledge, London 2010, s. 72-86. 
Śledząc rozwój współczesnego, zróżnicowanego kulturowo, wyobrażeniowo i klasowo, kosmopolityzmu w mobilnym świecie migrantów, warto zwrócić uwagę na specyfikę kulturowo-emocjonalną charakteryzującą migracje z Europy Środkowo-Wschodniej do „starej” Europy. Cytowani wyżej autorzy - Dubravka Ugrešić, Svetlana Boym, Milan Kundera, a należało by jeszcze dodać w tym kontekście przynajmniej Czesława Miłosza, zawsze podkreślali europejskość swoich literatur, opartą właśnie na kosmopolitycznym ideale trans - i ponadnarodowej komunikacji. Svetlana Boym wprost utożsamia tęsknotę za Europą z utratą kosmopolitycznej podstawy, odczuwaną przez wschodnioeuropejskich twórców i intelektualistów w komunistycznym reżimie i widzi w niej impuls do antykomunistycznego oporu: „Europa była ideą transnarodową, opartą na obywatelskim ideale związku wolnych miast. Sarajewo-Lubljana-Budapeszt-Belgrad-Zagrzeb-Plowdiw-TimisoaraBukareszt-Praga-Kraków-Lwów/L'viv-Vilnius[/Wilno]-Tallin-Leningrad/ Petersburg-Gdańsk/Danzig, lista jest o wiele dłuższa. [...] W krajach byłego bloku sowieckiego czy Jugosławii nostalgia za Europą była formą oporu przeciwko sowieckiemu lub narzuconemu przez Tito [czy Ceauşescu - przyp. D.K.] oficjalnemu internacjonalizmowi, jak równieź nacjonalizmowi ${ }^{39}$. Etos antykomunistycznego kosmopolityzmu zwróconego ku Europie w czasie transformacji pokomunistycznych zderzył się dość boleśnie z rzeczywistością, w której Europie Środkowo-Wschodniej wyznaczono status nie do końca wyartykułowanej, ale implikowanej na wiele sposobów gorszości czy też podrzędności. I właśnie ten brak określenia spycha Europę Środkowo-Wschodnią na peryferie - staje się ona graniczną przestrzenią niejasnych fantazji o typie orientalistycznym, fantazmatem inności, strefą nienazwanej pustki, którą można dowolnie zapełniać niesprawdzoną wiedzą. To z tej właśnie przestrzeni amorficznego pogranicza nadchodzą do starej Europy „nowi barbarzyńcy" - w tym autostereotypie widać pragnienie odebrania uogólnionemu podmiotowi europejskiemu jego nazewniczej władzy.

Najczęstszym sposobem realizacji tego celu jest strategia reaktywnej autokonstrukcji (autostereotypizacji, autoorientalizacji, autogroteski) ${ }^{\mathbf{4 0}}$.

39 S. Boym The Future of Nostalgia, s. 228-229.

40 Lista tytułów może być bardzo długa, włączywszy Gombrowicza, Choromańskiego, z nowej literatury zob. B. Helbig-Mischewski Anioły iświnie. WBerlinie!!, Wydawnictwo Forma, Szczecin 2005; L. Oświęcimski Klub Kiełboludów, Wydawnictwo Nieudaczników, Berlin 2002; dla perspektywy porównawczej zob. dokument The Romanians are Coming, reż. J. Bluemel, opowiada A. Fechete Petru, Keo Films i Channel 4, seria dokumentalna luty-marzec 2015 (i komentarz w artykule Cristiny Şandru w niniejszym numerze). 
W odpowiedzi na (prawdopodobnie) przesadzone, pełne uprzedzeń lub stereotypizujące przedstawienie migranta przez społeczność kraju przyjmującego migrant uprzedza niejako ten ruch (lub odpowiada na rozpowszechnione już stereotypy) i przejmuje stereotyp jako materiał do dalszej obróbki. U Czerwińskiego autostereotypizacja służy podkreśleniu kandydowskiej naiwności bohatera-Gustawa w zderzeniu z determinizmem sytuacji migranta:

- W takim razie, jakie prace są dla nas w tym kraju?

- Jak to jakie? Gówniane.

- Z całym szacunkiem, przyjacielu, gówniane prace są dla gównianych ludzi.

- My jesteśmy gównianymi ludźmi, szanowny kolego. My. (87)

Gustaw w końcu przyjmuje do wiadomości swój status, ale odmawia zgody na to, że jego prawdziwa praca - scenariusz wplatający w życie migrantów w Dublinie baśniową osnowę „Małego Księcia” - nie zainteresuje nikogo właśnie dlatego, że jest napisany przez Polaka. Narrator Konrad próbuje mu to wyjaśnić: „Nie potrzebują nas do pisania scenariuszy! Spojrzałem na niego, był kompletnie sad and down i patrzył, jakbym mu zabił rodzinę or something" (262). W powieściach Czerwińskiego, pisarza włączającego w tekst swych powieści nowy system językowy - mieszankę polskiego i angielskiego, stosowaną przez Polaków na Wyspach, a w jego powieściach zyskującą status nowego twórczego środka wyrazu - migracja to ścieranie się niewspółmierności, a decyzja o emigracji jest zazwyczaj tyle konieczna, co absurdalna. Migrant w Przebiegum życiae to osoba, która kieruje się nadmiarem wyobraźni i niedostatkiem poczucia rzeczywistości. A ta szykuje mu bardzo bolesne zderzenia, od irlandzkiej pogody, odbieranej przez bohatera jako czyste szaleństwo, przez kurki z wodą, enigmatycznie osobne, jak nigdzie na kontynencie, po język angielski w irlandzkim wydaniu, niedoartykułowany, nieporządny i niezrozumiały. Intensywnej autostereotypizacji Polaka-migranta w wielu przypadkach nowej prozy migracyjnej odpowiada tendencja do stereotypizacji Brytyjczyków/Irlandczyków. Dialog Gustawa z Konradem (ostatecznym narratorem-dziedzicem Gustawowej spuścizny), który codziennie prowadzą w formie porannej rozrywki w kolejce Luas, pokazuje jednoczesny manewr auto- i stereotypizacji: Gustaw i Konrad są w tym dialogu Anglikami, którzy wypowiadają się na temat Polaków: „Mówią po angielsku i próbują udawać Brytyjczyków, parodiując pretensjonalny akcent i ton angielskich wyższych sfer. Rozmowa przypomina trochę skecze Monthy Pythona. [...] GUSTAW: O mój Boże! Co za 
barbarzyńcy. KONRAD: Tak, mój przyjacielu. Ale to nie wszystko. Mają w zlewie tylko jeden kran! GUSTAW: Nie ma mowy! Nic więc dziwnego, że wpuszczono ich do naszej starej dobrej Europy niejako awansem. [...] Gustaw: [...] Jeśli przyrównalibyśmy Europę do istoty ludzkiej, ci ludzie z pewnością byliby jej rękami" (177-178). Stereotyp działa jako tego rodzaju nadmiar w strategii przedstawieniowej, który pomaga przezwyciężyć ograniczenia dyskursów narodowych ciązących na pisarzu emigracyjnym i, w procesie dialogowego obnażania przywar każdej społeczności, otwiera nowe moźliwości komunikacji międzykulturowej, której podstawą mogą, owszem, stać się performatywne nawiązania do stereotypów. Nie jest to komunikacja sterowana nakazami abstrakcyjnej polityki wielokulturowości.

Proces „nazywania” - określania się kraju przyjmującego wobec społeczności napływowych - obejmuje spektrum możliwości definiowania migranta jako innego i, bez względu na to, czy będzie to włączający, otwarty dyskurs, czy stereotypizacja ocierająca się o mowę nienawiści, jedno jest charakterystyczne: inny w swej funkcji wzmacniania podmiotu definiującego pozostaje zazwyczaj niezmienny, zamknięty w swej określoności. Jak pisze Inga Iwasiów w tekście o przydatności teorii Gayatri Chakravorty Spivak dla polskiego dyskursu feministycznego: „w ramach emancypacyjnych dyskursów rozumiemy już własną wielowymiarowość, przyjmujemy postulat różnorodności, ale nie dajemy prawa do niej «Innemu », który w tej sytuacji pozostaje bytem fantazmatycznym" ${ }^{\mathbf{4 1}}$. Współczesny migrant (czytaj autor, który migranta czyni bohaterem swojej opowieści) jest dość dobrze obeznany z mechanizmami dyskursu „othering", co więcej, sam z tych mechanizmów z chęcią korzysta, obserwując swoje nowe otoczenie. W ten sposób fantazmatyczność innego staje się wzajemna i nabywa cech dialogowości: już nie ,ja” skonstruowane na podstawie określonego przeze mnie innego jest głównym autorytetem ani teź nie sam fantazmat, któremu w geście gościnności oddaje się głos jako ofierze-subalternowi, lecz nawzajem konstruujące się fantazmaty, których dialog polega na wydzieraniu sobie nawzajem co tłustszych kąsków z kotła aromatycznie doprawionych stereotypów w celu, prawdopodobnie, ustanowienia własnego, autonomicznego głosu.

Jest to propozycja pragmatycznego podejścia do autoorientalizujących czy autostereotypizujących ekscesów obecnych w polskiej literaturze tematyzującej przekraczanie granic i kontakt z Europą Zachodnią. Byłaby to więc

41 I. Iwasiów Granice. Polityczność prozy i dyskursu kobiet po 1989 roku, Uniwersytet Szczeciński, Szczecin 2013 , S. 45 . 
kontra do pojawiających się nie tylko wobec nowej migracyjnej literatury zarzutów, że autostereotypizacja to technika wskazująca na poddanie się wewnętrznej kolonizacji i przyjęciu bez protestu i walki, pozycji podrzędności wyznaczonej nam w nowym, europejskim rozdaniu przez hegemona zastępczego, czyli Europę Zachodnią ${ }^{42}$. Rzecz jasna, zabawa w przedstawianie siebie jako tożsamościowy wybryk Europy (fantazyjne projekcje Stasiuka w Jadac do Babadag i Fado), a być może nawet jako Europy niegramotny Inny (jak w Przystupie Grażyny Plebanek, gdzie tytułowa bohaterka to antropologicznie zawłaszczony podmiot lokowany na granicy między niepełnosprawnością intelektualną a kozłem ofiarnym), to rzeczywiście objawy uwewnętrznionego i nieuświadomionego upodlenia utrzymującego się po sowieckim skolonizowaniu, a rzutującego na polskie poczucie własnej podrzędności w Europie w ogóle, natomiast samo przejęcie i własne użycie stereotypu to początek jego podważenia i odrzucenia.

Ale jak dowodzić empirycznie linii interpretacyjnej, że autostereotyp jest symptomem poddania się kolonizacji, skoro większość polskich emigrantów raczej dowodnie manifestuje narodową dumę, widoczną chociażby w tym, jak do granic absurdu posuwają niekiedy nostalgię za kuchnią narodową (wszyscy możemy zrozumieć import kiełbasy, pierogów, kapusty kiszonej i ogórków, ponieważ to nasze narodowe koordynaty, ale import mleka UHT, groszku w puszce czy zupek chińskich - to produkty obecne na każdej polskiej półce w Tesco, Sainsbury's czy Carrefour w Wielkiej Brytanii, nie tylko w specjalistycznych sklepach - każe się zastanowić nad mechanizmami psychologicznymi owej nostalgii). W moim przekonaniu długa historyczna perspektywa raczej pokaże żywotność romantycznych modeli narodowej tożsamości, rozbudzanej wśród migrantów jakby od nowa, a mniej objawy niezwalczonego skolonizowania. Literackie reprezentacje zaś, oparte na figurach wywodzonych ze stereotypu wskazują na potrzebę radzenia sobie z trudną rzeczywistością migranta przez poetykę satyry, ironicznego przepracowania syndromu ofiary i, co chyba najważniejsze, walki z pokusami narodowej megalomanii, tak łatwo znajdującej sobie drogę do rozumu i, przede wszystkim, serca Polaka, który wyemigrowat. U Czerwińskiego nostalgia tego typu jest

Dariusz Skórczewski interpretuje autostereotypizację jako dowód na poczucie gorszośc podmiotu wschodnio-środkowoeuropejskiego, a to z kolei jako symptom nieprzepracowanego kolonialnego zniewolenia: „Ambiwalencja tego rodzaju [pogarda i podziw dla hegemona] to zjawisko charakterystyczne dla postaw, jakie reprezentują ludy podporządkowane obcej dominacji pod każdą szerokością geograficzną", D. Skórczewski Teoria - Literatura - Dyskurs. Peizaż postkolonialny, Wydawnictwo KUL, Lublin 2013, s. 310. 
traktowana czysto użytkowo, ale i to wpisane jest w ironiczny komentarz: „okazjonalnie wlokłem się do Russo-polo mini-martu «Rusałka» na Meath, żeby kupić parę kefirów na kaca. [...] Nie po to wyfaczyłem sięw drugi koniec Europy, żeby kupować polskie żarcie, ale serio, kefir to jeden z tych wynalazków wschodniej cywilizacji, który nie dotarł jeszcze do tej części świata, więc dziękowałem Wszechmogącemu za to, że sprowadził kefir do krainy bajobongo wraz z naszym dzielnym narodem" (272-273).

Literatura Polaków osiadłych na Wyspach Brytyjskich po przystąpieniu do Unii Europejskiej w 2004 roku pokazuje pewne stałe elementy pisania emigracyjnego. Obserwuje się w niej potrzebę pisania w odpowiedzi na dyskursy narodowe (konstrukcje tożsamościowe i historyczne, często odbierane jako opresyjne $\mathrm{e}^{43} \mathrm{i}$ dialog z tradycjami literackimi. Literatura ta prezentuje także nowe cechy: aktywny komentarz o kulturze kraju przyjmującego, z włączeniem stereotypowych reprezentacji jego mieszkańców jako działania odwetowego i świadome zawłaszczanie języka angielskiego w procesie kreowania nowego, hybrydycznego języka literackiego. Ów emigrancki „Ponglish” po części odzwierciedla codzienny, naturalnie zhybrydyzowany język imigranta, który nie ma czasu rozdzielać języków w zdyscyplinowanym przekładzie i po prostu je miesza, po części zyskuje status autonomicznego języka literackiego, niczym pidgin w literaturze karaibskiej.

Przegląd strategii autoprzedstawień wobec społeczności kraju przyjmującego byłby najciekawszy, gdyby obejmował wszystkie kraje, w których powstaje literatura migracyjna Polaków (w tym wszystkie języki,w których jest tworzona). Na taką syntezę trzeba chyba jednak trochę poczekać, tymczasem w krytyce przewaźa terytorialność, co jest ważne dla budowania spójnego obrazu literatury jako systemu wpisanego w rzeczywistość polityczno-społeczno-kulturową, ale może też skutkować izolowaniem takich motywów, tematów czy strategii przedstawieniowych, które tworzyłyby nowe całości w planie porównawczym. W przypadku literatury migracyjnej jest to rzeczywistość graniczna - a przynajmniej ukazująca działanie granicy państw, języków, habitusów i codzienności, którego doświadcza podmiot-migrant, a które jest podstawą tworzenia się diaspor jako świadomych siebie społeczności. Scalanie tych terytoriów literatury w szerszy

43 Zmaganie się z bardzo esencjalistycznie, żeby nie powiedzieć, stereotypowo przedstawioną polskością stanowi główny tematyczny nurt anglojęzycznej powieści A.M. Bakalar Madame Mephisto (Stork Press, London 2012). Na ten temat nakłada się wątek zaangażowania umęczonej polskością bohaterki - imigrantki w Londynie - w globalny biznes nielegalnego handlu marihuaną, który staje się synonimem wolności i kosmopolitycznego wtajemniczenia. 
horyzont komparatystyczny będzie jednak kluczowe dla zbadania, jak literatura migracyjna Polaków rozwija świadomość globalnego świata i jego czasami zaskakujących rozłączności oraz czy tworzy ponadterytorialną całość. W transnarodowej i transkulturowej perspektywie migracja okazuje się nowym, globalnym systemem społeczno-kulturowym. Stwierdzenie niby oczywiste, ale metodologicznie jest to wielkie wyzwanie - jak badać system globalnych przemieszczeń, a z nim, wyobrażeń, polityk, kontaktów poprzez różnice? Globalne ujęcia mają tendencję do metonimicznego uogólniania przypadków, znowu ujęcia lokalne, terytorialne, odcinając szerszą perspektywę, zamykają analizę migracji w niewystarczającym już formacie biegunowej relacji ze starym krajem i nowym. Globalny kontekst współczesnych ruchów migracyjnych funkcjonuje w naszej świadomości zazwyczaj jako wyobrażenie skali. Tymczasem globalność to też trajektorie szlaków migracyjnych i style zachowań typowe dla korporacyjnego zatrudnienia i umasowionej kultury, a także zupełnie już niemarginalne diaspory mobilnej i nomadycznej sily roboczej.

Masowa migracja na Wyspy Brytyjskie po przystąpieniu Polski do Unii Europejskiej nosi w sobie znamiona epickiego przełomu i z pewnością dorobi się ogromnego archiwum. Na razie jest to literatura bardzo nowa, krzywdą dla niej i ryzykiem dla krytyka byłoby wysnuwać na jej temat jakiekolwiek uogólniające wnioski, a wszelkie próby jej całościowego ujęcia, w tym oceny, muszą przyjąc tryb spekulatywny. Zwraca jednak uwagę w tej literaturze, i to zarówno w prozie, jak i w poezji, swoisty kosmopolityzm czy właśnie kosmopolityka, wyłaniająca się z krytycznej obserwacji nowego otoczenia. U Czerwińskiego poszukiwanie wymiaru epickiego jako formatu dla kosmopolitycznej perspektywy daje interesujący rezultat. W Przebiegum życiae epickość jest budowana na bazie metafikcyjnej narracji. Codzienność migranta to stale powtarzające się schematy bezsensu, przekładane na hybrydyczny język, ponieważ tylko w takim imigrant może pobawić się w autochtonizację:

O czym innym właściwie można gadać, kiedy się jest fałszywym turystą z Bulandy [...] Pogoda nie była za dobrym tematem do rozmowy, bo w krainie bajobongo nie ma żadnej pogody, tudzież jest na okrągło ta sama. Job nie nadawał się do tego neither, no bo jak długo można dyskutować o przekładaniu zaklejonych kartonów, układaniu ich na wózku, pchaniu wózka przez dwadzieścia metrów i wyrzucaniu kartonów do Jabby. ... No shit, man, to nie jest żaden sakra ty vole temat, żeby pisać o tym koorva książki. (27o) 
W tej męczącej, bezczasowej teraźniejszości wpisywanie się w wielkie narracje literacko-narodowe: Matego Księcia i (z oporami i autoironicznie) Dziadów, umożliwia nadanie życiu narracyjnego, a więc prawdopodobnie teleologicznego toku. Gustaw pisze, i to jest jedyna akcja, jakiej się poddaje świadomie i z pasją. Migracyjne pisanie (Gustawa) ma szansę stać się transformacyjną siłą w myśleniu o kondycji migranta, jeśli z klaustrofobicznej ciasnoty imigranckiej codzienności (crappy haus, Luas, beznadziejne agencje pośrednictwa pracy i samo dno do Gustawowego de profundis, czyli enigmatyczna fabryka, której celem jest nie produkować, lecz niszczyć, a której średni poziom zarządczy jest, typowo dla Irlandii w oczach Gustawa/Konrada, ledwo piśmienny) powstanie, w trybie organicznym, projekt kosmopolityki jako formy rozumienia świata opartej na mikropraktykach oporu wobec większościowej dominacji. Brzmi rewolucyjnie, ale chodzi nie o przewrót, lecz o takie pisanie i czytanie narracji migracyjnych, z których wyłania się zarys transnacjonalizmu ${ }^{44}$ i transnarodu ${ }^{45}$, które to formy moźna sobie wyobrazić jako „przestrzeń wymiany i uczestnictwa wszędzie, gdzie występują procesy hybrydyzacji i gdzie wciąż istnieje moźliwość, aby kultury wytwarzały się i tworzyły poza bezwzględnie konieczną mediacją centrum" "46. Transnaród byłby to więc niesystemowy zespół nowych form świadomości diasporycznej, rozwijających się nie tylko w relacji do większości, ale też w relacji do innych diaspor, i do globalizacyjnych zagrożeń ze strony uniwersalizującego się w systemie korporacyjnym kapitału, ale też do globalizacyjnych szans na upodmiotowienie.

W nowej prozie migracyjnej pisanej po 2004 roku dominuje portret migranta-subalterna, którego opowieść, mimo że ogranicza go przestrzeń podrzędności, wypracowuje konsekwentnie dyskurs transnarodowej kosmopolityki - i nie chodzi tutaj o to, jak bohaterowie nowej prozy migracyjnej ulegają urokom multikulturalizmu, lecz o to, że poddają się nieuchronnym procesom hybrydyzacji i kreolizacji, nawet jeśli dominuje u nich postawa migracyjnego patriotyzmu, realizowana jako nostalgie kuchenne (przywiązanie do polskich smaków i towarów). Pisanie migracyjne dzieje się na poziomie mocno zaznaczonej codzienności (nowość jest często przedstawiana w poetyce udziwnienia i przerysowania) i nakładającego się na nią poziomu transnarodowych

\footnotetext{
44 F. Lionnet, S. Shih Introduction: Thinking Through the Minor, Transnationally, w: MinorTransnationalism, ed. F. Lionnet, S. Shih, Duke University Press, Durham 2005, S. 1-23.

45 B. Ashcroft Transnation..., s. 73.

46 F. Lionnet, S. Shih Introduction..., s. 5.
} 
dyskursów obecnych w globalnym obiegu. Na obu tych poziomach dokonują się procesy hybrydyzacji i kreolizacji. Z jednej strony często występujące strategie auto- i stereotypizacji wpisują obraz migranta-Polaka w dwuwymiarowy schemat Ja/Inny, tutaj z tą jednak dodatkową komplikacją, że Ja to Inny projektowany przez Innego, który z kolei nie jest modelowym „ja” (podmiotem społeczności przyjmującej, nazywającej migranta jako obcego/Innego), lecz Innym dla Innego, którego projektuje. Z drugiej strony ten schematyzm jest pozorny, ponieważ nie jest celem samym w sobie, ale stanowi podłoże szerszego kontekstu, który ze względu na formę narracyjną nazwę epickim, a ze względu na ideologię - kosmopolitycznym.

Niewspółmierności napotykane przez imigrantów w nowym miejscu są z pewnością jednym z najciekawszych i kulturowo produktywnych doświadczeń ludzi, którzy zdecydowali się na zmianę miejsca zamieszkania i pracę poza własnym krajem. Sama codzienność dostarcza bogatego repertuaru zadziwienia w pejzażu miejskim, społecznym czy w przestrzeni domowej. Co ciekawe, w opowieściach imigrantów nie napotkamy na ogół wrażenia przesunięcia w czasie do przyszłości - imigrant nie widzi specjalnej różnicy cywilizacyjnej w relacji do swojego kraju (Czerwiński wręcz gra odwracaniem cywilizacyjnych proporcji Wschód - Zachód), lecz raczej ogromną różnicę polityczno-społeczną. W migracyjnych opowieściach postkolonialnych przybysz z (byłych) kolonii ma okazję uświadomić sobie w najbardziej materialnym wymiarze przepaść między metropolią jako centrum kreowania znaczeń, a swoim krajem - (byłą) kolonią, jako peryferiami bez żadnej siły semantycznej ${ }^{47}$. W Szatańskich wersetach Salmana Rushdiego bohater, Saladin Chamcha, wspomina swoje pierwsze dni w prywatnej szkole angielskiej jako koszmar nieznajomości kodów kulturowych, których najbardziej traumatycznym wcieleniem jest wędzony śledź - kuriozalny element tradycyjnego angielskiego śniadania i jednocześnie metafora Anglii, dostępnej tylko dla wtajemniczonych. U Czerwińskiego od poziomu zadziwienia mocno znaczącymi kulturowo drobiazgami: „przeżywał właśnie swoje pierwsze bliskie spotkanie z irlandzką kanalizacją i zachwycał się magiczną umywalką z dwoma kranami. Jeden z nich dostarczał wodę lodowatą, wrzątek zaś dostępny był w tym drugim" (70), przez strefę udziwnienia - transkrybowany fonetycznie irlandzki angielski funkcjonuje na zasadzie egzotycznej ciekawostki,

Zob. V.S. Naipaul Marionetki, przeł. M. Zborowska, Książka i Wiedza, Warszawa 1971; l. Kincaid On Seeing England for the First Time, "Transition" 1991 no. 51, s. 32-51; G. Lamming The Occasion for Speaking, w: tegoż The Pleasures of Exile, Pluto Classics, London 2005 (1960), s. $23-50$. 
przechodzimy do przestrzeni przemieszanych, co jest szczególnie widoczne bezpośrednio w sferze języka. Nieposkromiona hybrydyzacja języków, której ulega narrator, zapewniając (autoironicznie), że jest to środek wyrazu artystycznego, poza oczywistym efektem estetyczno-retorycznym ma kluczowe znaczenie dla powieściowej kosmopolityki. „Wszystko to czyniło go największym sakra pojebem to ever walk the ziemia mleczno-miodnej krainy bajobongo" (24) - w anglopolskim interjęzyku, okazjonalnie okraszonym innymi, kulturowo nieprzypadkowymi, zapożyczeniami (Bulanda - NB poza glosariuszami umieszczonymi w książce), artykułuje się kosmopolityka (nie) przekładalności. Hybrydyzacja tyle udziwnia, co oswaja język, a tym samym jest jedynym sposobem oddającym złożoność doświadczenia migranta. Koryguje narcystyczny optymizm, z którym migrant przyjeżdża do nowego kraju, otwiera zamknięte rewiry podrzędności, na które migrant wydaje się być skazany, i wyznacza kierunki utopijnej, ale koniecznej, przyszłości. Nie obejmuje jedynie języka, ale cały system przedstawień - narrator sięga w swoim interjęzyku do nieograniczonego archiwum kultury popularnej, mówi językiem piosenek, filmu (Gwiezdne Wojny - niezbędna pokoleniowa i ucieczkowo-utopijna rama odniesień) i literatury. Literackie aluzje są częścią interjęzyka, tak samo jak język właściwy - razem z innymi odniesieniami formułują transjęzykową i transnarodową (w sensie przecinania kultur i tradycji narodowych, mniej lub bardziej stereotypowo lub ironiczno-patetycznie komunikowanych) świadomość, a z nią, krytyczną kosmopolitykę.

Kosmopolityczna epika, bo do tego chyba gatunku, postulowanego przez Bogusława Bakułę i Ingę Iwasiów, doszliśmy w refleksji nad współczesnym migracyjnym pisaniem na przykładzie prozy Piotra Czerwińskiego, nie kończy się jednak na migranckiej rzeczywistości tu (tam) i teraz. W Międzynarodzie Czerwiński rozwija wizję makroutopii - Polski jako narodu zrodzonego z wygnańczej bezdomności na dalekiej wyspie, w fazie ubóstwa uszlachetnionego suwerennością, dzielącego się wszystkim z innymi niechcianymi ludami tej ziemi: „Polacy mieli guzik z pętelką, a także buraki oraz oczywiście niepodległość" (29), a ściągają na nią ci, których „również nie chciał w tamtych czasach nikt na świecie" (30). Gdy na wyspach, na które zesłano Polaków jako wyklęty lud ziemi i na których przemieszali z innymi, jak on niechcianymi nigdzie ludami, włączając w to fosforyzujących Bikiniarzy z Bikini, karmiących się kuchnią nukleo (30), odkryto uran, jedyne źródło energii stosowane w owej przyszłości, w Polsce A i Polsce B zapanował „bezkrytycznie chorobliwy dobrobyt". I ten właśnie kraj, ze względu na brak rąk do pracy (Polacy, jako właściciele kopalni, nie mają powodu, żeby w nich pracować), otwiera swój 
rynek dla Anglików, mieszkańców biednego, zacofanego kraju północno-zachodniej Europy (48), ,który stał się największą ofiarą światowego kryzysu, przez co nie przedstawiał sobą w tamtych czasach niczego, co miałoby jakąkolwiek wartość dla zachodniej cywilizacji. Anglicy zajmowali się głównie wędrowaniem po świecie; szukali pracy wszędzie, gdzie chciano ich wpuścić, a także w większości tych krajów, które tego nie chciały" (48-49). Niestety ta quasi-sielanka zmierza do apokaliptycznego końca, relacjonowanego przez narratora $\mathrm{z}$ atolu 44. Można tę futurystyczno-profetyczną fantazję interpretować jako „odpisywanie centrum w odwecie"48, wszakże role dominujących i podrzędnych ulegają, w kontekście polskich migracji na Wyspy, odwróceniu. Ale odwet ujęty w ramę autoapokalipsy nie nosi znamion triumfu, lecz ironicznej przestrogi.

\section{Konkluzje: kosmopolityzm jako futurystyka}

Odwetowa fantazja Międzynarodu pozostaje w bliskim dialogu z kosmopolityką subalternów z Przebiegum życiae i razem te dwie powieści wyznaczają szlak nowego kosmopolityzmu migracyjnego pisania: od świadomości podrzędnych do agonistycznego głosu w kosmopolitycznych projektach. Migranci u Czerwińskiego, ale też w wielu innych utworach, są zupełnie wyalienowani - nie mają dostępu do komunikacji interkulturowej, mimo że teoretycznie mieszkają w społeczeństwach wielokulturowych; ich pozycja i przestrzeń, którą zajmują, są marginesowe i mają pozostać niewidoczną strefą minimalnego przeżycia przy ogromnej mobilizacji sił, a lokalna (autochtońska, jak Czerwiński lubi to nazywać) kultura postrzegana jest przez pryzmat egzotyzmu jako idiosynkrazja prymitywnych ludów. Migranci są również uwięzieni w swojej przemieszczonej i groteskowo zmieniającej się poprzez granice polskości. Mają pełną świadomość, jak bardzo patetyczno-beznadziejny staje się ten fragmentaryczny fantazmat, podtrzymywany przez replikujące się autostereotypy.

Autoekspresja wydaje się jedyną drogą wyjścia z klaustrofobicznej podrzędności migranta. Mulitlingwalizm czy też dynamiczny interjęzyk anglopolski, trademark Przebiegum życiae, pozwala znieść granicę między wzajemną niezrozumiałością i nieprzekładalnością języków. Tym samym ta hybrydowa i hybrydyzująca forma wyrazu otwiera (się na) róźnicę kulturową jako produktywne i transformujące doświadczenie. W Przebiegum życiae

48 S. Rushdie The Empire Writes Back with a Vengeance, "Times" 3.07.1982. 
doświadczenie migracji niszczy w końcu (prawdopodobnie) migranta, ponieważ nie jest mu dane znaleźć ujścia dla swojej potrzeby komunikacyjnej - Gustaw nie akceptuje świata, w którym jego miejsce imigranta jest określone i niezmienne. Pisanie scenariusza jest jego własnym projektem autokosmopolityzacji i jednocześnie strategią przeźycia, lecz aby projekt odniósł sukces, konieczna jest moźliwość przekroczenia zinstytucjonalizowanej bariery. W jego wypadku hybrydowy język migranta nie jest więc szansą na uwolnienie się od alienującej kondycji przez transformującą siłę artystycznego wyrazu, lecz recyklingiem bezużytecznych językowych resztek na podobieństwo odpadów w fabryce, w której jego zadaniem jest je niszczyć i nie pytać, co w nich jest i dlaczego pozbywają się zapakowanych pudeł. Gustaw znika, mając do wyboru to albo pozostanie w nadanej migrantowi sferze abiektu. W tym kontekście przyszłość, która w Międzynarodzie rozwija się jako spekulatywna i, do pewnego, kontrolowanego stopnia, odwetowa fantazja o odwróconym (i mocno przerysowanym, zgodnie z poetyką całości) porządku dominacji, okazuje się przede wszystkim kosmopolityczno-ponadczasową refleksją na temat niezmiennego formatu historii jako dziejów (lokalnie zmiennych) dominacji jednych kosztem drugich w znojnym ruchu w kierunku apokalipsy. 


\section{Abstract}

\section{Dorota Kołodziejczyk}

UNIVERSITY OFWROCLAW

In Search of Migrant Writing: The Cosmopolitics of Fiction from the British Isles

Locating the discussion about Polish literature written on the British Isles after 2004 at the intersection of postcolonial and post-dependence studies, the article aims to show the need to formulate critical paradigms that would be able to include writings characterized by intense wordliness. This term, which is key for migration writing, coined by Edward Said and signifies an active awareness of the world (agency and subjectivity). It develops in migration writing as'cosmopolitics' - the cosmopolitanism of contemporary mass migrations. Presenting Piotr Czerwiński's fiction as a case study, Kołodziejczyk traces processes of going beyond the nation/migration dichotomy in today's mobility, nomadism and other forms of migration.

\section{Keywords}

migration, migration writing, worldliness, cosmopolitanism, cosmopolitics 